\title{
From Édouard Glissant's “The Open Boat” to the Age of Mass Migration
}

At once poetic prose fiction, historical account, and allegory of the transatlantic slave trade, Édouard Glissant's “The Open Boat” serves as a preamble to Poetics of Relation (1990) - a philosophical essay in which Glissant redefines identity outside its traditional boundaries by positing a fluid, changing network of exchanges and contacts with others. In Glissant's view, identity is neither static nor self-contained but shifting and rhizomatic: It is relational, multiple, and unpredictable; it eludes all cultural certainties, opposes all forms of rootedness, and challenges the stability of communities (from ethnic groups to nation-states) that define themselves primarily in opposition to outsiders. Glissant calls this new way of apprehending the world Relation, and the process whereby Relation comes into being creolization. Creolization is not a mere concept: It is happening in the wake of globalization and the exponential growth of intellectual, artistic, and cultural interactions it generates. Paradoxically, creolization also works as a bulwark against globalization understood as the neoliberal economic system that leads to an unequal distribution of wealth and is responsible, in no small measure, for the current mass migration into Europe. This chapter, however, intends neither to assess the pros and cons of globalization nor to probe the hows and whys of the migrant crisis. Rather, it endeavors to understand the challenges migration entails both for the displaced populations and the societies into which they integrate willy-nilly. Starting from "The Open Boat," and relying on such Glissantian concepts as trace and errantry, this chapter identifies the connection, however tenuous, that exists between "the Africans who lived through the experience of deportation to the Americas" ("Open Boat” 5) and the migrants of today. Immigration is further discussed not as a clash between cosmopolitan and narrow-minded sensibilities but as an ipso facto state of negotiation between host nations and newcomers. In an effort to de-dramatize a situation the consequences of which are yet to be known, this chapter ultimately tries to imagine what kind of new identities will spring from circumstances that are not new but nevertheless unprecedented in magnitude.

\section{Slave Trade, World Trade, Migration}

“The French Caribbean," Glissant writes in Caribbean Discourse (1981), "is the site of a history characterized by ruptures and that began with a brutal dislocation, the slave trade" (61). A decade later in “The Open Boat," Glissant exhorts his reader to imagine what this dislocation was like for the captives in the hold of the slave ship. Glissant describes the "deported" Africans as "[w]orn down, in a debasement more eternal 
than apocalypse" (6). But, Glissant warns, "that is nothing yet" (6), for the Middle Passage has repercussions beyond the event itself and long after the victims' lifetime. After describing the harrowing experience of the Middle Passage, Glissant endeavors to make intelligible the psychological state of captives confronted with what he calls the unknown, a term which designates three different instances. First, the unknown is the hold of the slave ship-a place where human beings are uprooted, dissocialized, and depersonalized. Second, it is the marine abyss in which so many captives, dead or alive, were casually jettisoned. Finally, the unknown is the New World, a place where the everyday has become unreal, and the ancestral land a vanishing memory. "The Open Boat” is part of a small group of fictional works, from Fred D’Aguiar's Feeding the Ghosts (1997) to Manu Herbstein's Ama, A Story of the Atlantic Slave Trade (2001) and Daniel Black's The Coming (2015), which tell the story of the Middle Passage from the vantage point of the victims. ${ }^{24}$ However, "The Open Boat" stands out not only because it does not fully meet the criteria of fiction writing ${ }^{25}$ but because, quite unexpectedly, it turns one of the most dreadful events of world history into a positive experience with a universal scope. Indeed, Glissant compares the Middle Passage to a birth, and while he is not the only author to use this simile, he makes his whole theory of Relation hinge on it. ${ }^{26}$

While describing the first dread of the hold as "a fall in the belly of the boat" (6), Glissant re-interprets the hold as a womb wherefrom a new people came. Thus, in spite of all those who have been sacrificed, Glissant sees the experience of the hold as

\footnotetext{
24 This list is by no means exhaustive. Other noteworthy novels that do not exclusively focus on, but devote significant segments to, the Middle Passage and its victims are, in chronological order, Martin R. Delany's Blake; or the Huts of America (1859-1861); Alex Haley's Roots: The Saga of an American Family (1976); Toni Morrison's Beloved (1987); Barry Unsworth's Sacred Hunger (1992); Lawrence Hill's The Book of Negroes (2007); and Yaa Gyasi's Homegoing (2016). Bernardine Evaristo's Blonde Roots (2009) should be added to this list even though Blonde Roots depicts a world in reverse in which slaves are white and masters black.

25 "The Open Boat" is not a novel. It is a short piece comprising fourteen paragraphs running over five pages. What really differentiates it from such works as Feeding the Ghosts, Ama, A Story of the Atlantic Slave Trade, and The Coming, however, is its unconventional use of fiction writing rules. "The Open Boat" tells a story (the Middle Passage as birth) with a plot (the psychological experience of the captives), characters (the captives, the descendants, and the readers), and a dénouement (transcending the trauma of the Middle Passage), but all these elements of fiction writing are used as introductory material for philosophical theories later developed in Poetics of Relation.

26 The idea of the Middle Passage as birth already pervades Robert Hayden's "Middle Passage" (1962) of a few decades earlier: "Middle Passage: / Voyage through death / to life upon these shores" (48). And it anticipates Caryl Phillips's description, in The Atlantic Sound (2001), of Sullivan Island, the place where many slave ships would unload their cargo for the auction block of nearby Charleston, South Carolina: "An arrival in America. Having crossed the Atlantic in the belly of a ship. An arrival. ... Step ashore, out of sight of Charleston. To be fed, watered, scrubbed, prepared. To be sold. ... An arrival. Low, low land. Water. The mainland lying low in the hazy distance. Charleston. Farewell Africa. Welcome America” (257).
} 
a beginning, the emergence of a new humanity, a nothingness that has finally become knowledge, "[n]ot just a specific knowledge, appetite, suffering, and delight of one particular people” (8), he explains, "but knowledge of the Whole, greater from having been at the abyss and freeing knowledge of Relation within the Whole" (8). The word Glissant uses for knowledge in the original, connaissance, is more revealing as its Latin etymology (co-gnoscere) means to know with or together. Knowledge is built in relation with others; it is in the making and always renewed rather than ossified and imposed from outside. It is not a knowledge already framed in cultural certainties, and not a knowledge reduced to Glissant's own Creole community. It is an allencompassing knowledge conducive to what Glissant defines as Relation, which "is not made up of things that are foreign but of shared knowledge" (8). Relation, which started in the "nonworld"-that is, in the darkness and anonymous promiscuity of the hold-has grown into something new: the total world. The world as a totality, Glissant argues in Traité du Tout-Monde (1997), is already a reality that has changed the way human communities see themselves and their land: "The physical borders of nations have been made permeable to intellectual and cultural exchange, to the blending of opinions" (193; my translation). As a result, Glissant goes on, "the nation state is no longer able to protect from within the connection each individual has to the land" (193; my translation). Glissant is critical of attachment to soil, culture, race, or religion because it thwarts diversity and facilitates uniformization and homogeneity. Glissant calls such a mindset "continental thinking," and using his own Caribbean background as a paradigm, contrasts it with "archipelago thinking," which is another term for total world and Relation. As Glissant notes, "[t]he whole world is becoming an archipelago and becoming creolized" ("Unforeseeable” 290). This is particularly true of Europe, which "offers such a mosaic of languages and does not seek cultural standardization" (qtd. in Joignot; my translation). Glissant does not provide a political strategy toward the achievement of Relation, but he champions the cross-fertilization of ideas across cultures and continents, and more significantly, he believes in the power of imagination to have a positive impact in the world. As he states in Poetics of Relation: "No imagination helps avert destitution in reality, none can oppose oppressions or sustain those who 'withstand' in body or spirit. But imagination changes mentalities, however slowly it may go about this" (183). Unlike hard science, whose role is to find, observe, and establish facts, imagination can look into the future and suggest new ways of transforming the world. Glissant chose the word poetics to define his work because poetics encompasses both an aesthetic and innovative dimension. Indeed, the Greek etymology of poetics, poiesis, denotes creation, production, and composition. Modernity, according to Glissant, is violent and anticultural, "which means it tries hard to guarantee the open energy of the shock between cultures" (Poetics 197). In order to derail this movement of "deculturation," Glissant advocates resorting to the "imaginary," i.e., poetics: "Let us not stop with this commonplace: that a poetics cannot guarantee us a concrete means of action. But a poetics, perhaps, does allow us to understand better our action in the world" (199). The imaginary is 
not an instrument of concrete change, but it makes us aware of "the prophylactic violence of forms of deculturation" (199). The imaginary, Glissant further argues, "works in a spiral: from one circularity to the next, it encounters new spaces and does not transform them into either depths or conquests" (199). Finally, it "becomes complete on the margins of every new linear projection. It creates a network and constitutes volume" (199). The imaginary, one could argue, is a sine qua non toward the advent of Relation, and it is with this principle in mind that Glissant concludes "The Open Boat": "Our boats are open, we sail them for every one" (21).

\section{Captives and Refugees}

In 1990, when “The Open Boat” came out, Glissant's hopeful vision of a generous humanity sailing together to the four corners of the world was rivaled by images of a despairing humanity-that of the so-called boat people, Haitian refugees in the Caribbean and Vietnamese refugees in Southeast Asia, all fleeing persecution aboard rickety, overcrowded vessels that may either fail to reach safer shores or be turned away when they did. The tragedy of the boat people was still making headlines in the mid-1990s, and it bears a striking resemblance to the current tragedy of migrants and refugees trying to cross into Europe through the Mediterranean Sea. The locale and the victims have changed, but the situation is very similar. Of these exiles yearning for freedom, justice, and economic security, some die and some survive. Some find asylum in host countries, and some don't. Some become legal aliens, and some remain undocumented.

Comparing these displaced victims to the victims of the Middle Passage appears misguided since the latter were brought to the New World bound hand and foot to work as slaves on plantations while the former have been leaving war-torn zones, moribund economies, and oppressive regimes of their own volition (even when circumstances leave them little choice). Furthermore, the Africans were deported for a life of forced labor guaranteeing the economic prosperity of their masters. Conversely, migrants and refugees face either labor deprivation or "self-deportation," ${ }^{27}$ when they are not compelled, manu militari, to turn back. Whatever the scenario, the purpose of anti-immigration policies is to perpetuate the economic prosperity of nations that once enslaved Africans for ... economic prosperity. From this perspective, it can be

27 Self-deportation is a legal strategy whereby a host country encourages illegal aliens to go back to their home countries of their own volition. Rather than enforcing deportation laws, the host country seeks to make the life of illegal aliens unbearable either by denying them access to basic welfare or threatening to go after employers who hire them. The term is associated with a series of policies enacted in the United States in the 1990s. 
argued that the scourge of those shackled in the hold of slave ships and those huddled under the tarp of makeshift boats is the same: greed.

In "Creolization in the Making of the Americas" (1995), the original version for the first part of Introduction à une poétique du divers (1996), ${ }^{28}$ Glissant distinguishes three types of migrants to the New World. The first type is that of the "founding" or "armed migrant"-the Mayflower settler and his descendants who built "the economic power of the Northern Americas" (87); the second type is that of the "household migrant" who arrived "with his kitchen ranges, ... family pictures, [and] perhaps a business ability" (87); that migrant "provided the labour in the North, but ... remained dependent on the economic power of the [armed migrant]" (87); and the third type of migrant is the "naked migrant," whom Glissant describes as "the African deported by the Middle Passage, arriving with only traces of his original country and his languages, and with the difficult and progressively vanished memory of his gods" (87; emphasis added).

While the fate of the deported Africans of the slave trade era is not a yardstick by which the fate of the displaced migrants of today should be measured, Glissant's notion of the trace can help bridge the gap between both experiences. Glissant notes that the cultures that emerged from the plantation economy of the Americas did not proceed "from preserved folklores (as did the Irish or Italian people in the North), but from ... traces" (87) - traces that they would combine with "countless other elements, from China or India or the Middle East, and so on, with so many conflicts to resolve" (87). But Glissant, rather than point out the alienating effects of such an ordeal, prefers to emphasize its virtuous outcome: "Imagining and recreating from traces of memory removes a person far away from systems, far away not only from ideological thinking but even more from the thought of any imperative system" (87). "Trace-thinking," Glissant argues in Introduction à une poétique du divers, exposes "the false universality of system thinking” (17), ${ }^{29}$ which designates the logocentric tradition of the Western world that spawned the plantation system, neoliberalism, and the territorial instinct of modern nation-states. Interpreting Glissant's definition of the trace, Jarrod

28 The quotes in this paragraph come from a 2008 version of "Creolization in the Making of the Americas," which appeared in Caribbean Quarterly. The original version of this text was published in Vera Lawrence Hyatt and Rex Nettleford's 1995 Race and the Origin of the Americas: A New World View, a collection of essays arising from a symposium held at the Smithsonian Institution in 1991. Introduction à une poétique du divers was also published in 1995 by Presses de l'Université de Montréal. The better-known French version was published the following year, in 1996, by Gallimard, and its first part, which corresponds to "Creolization in the Making of the Americas," is titled "Créolization dans la Caraïbe et les Amériques" (11-32).

29 The original sentence reads: "La pensée de la trace est celle qui s'oppose aujourd'hui le plus valablement à la fausse universalité des pensées de système." I borrow “trace-thinking” for "pensée de la trace" and "system-thinking" for "pensées de système" from Jarrod Hayes, but the translation varies from one author to the next. For example, Jean-Luc Tamby translates the former as "trace thought" and the latter as "systematic thoughts," while Chris Bongie prefers "thinking of the trace" and "systematic thinking," respectively. 
Hayes argues that Glissant contrasts the trace "with an essentialist understanding of identity and uses the trace to define a kind of identity-in-movement" (142). The trace, Hayes goes on to say, is like the rhizome: It is "one particular manifestation of "poetics of relation' that defines identity in relation to others, to the Other-and values the relation with other cultures and peoples over an internal essence" (142). What Glissant's "trace-thinking" helps us understand, however, is that the "naked migrants" did not re-invent themselves ex nihilo: Old identities were lost, but traces remained and became an integral part of the new identities they forged through exchange with others. The same applies to modern-day migrants: Traces of their lost cultures have traveled with them and will influence their host cultures in unpredictable ways. Moreover, these migrants may arrive empty-handed, but they come with a claim-a claim to basic human dignity and protection, which is guaranteed, at least to those recognized as refugees, by international laws. ${ }^{30}$

The issue of the slaves taken across the Atlantic to work on the plantations of the New World remained conspicuously absent from political, let alone moral, debates until the end of the 18th century. The Enlightened notions of human rights had not yet started to influence international law, and those who condemned the immorality of the slave trade were few and diffident. Yet "The Open Boat" touches on this notion of claim on two occasions. First, when the narrator tells the captives that the "womb abyss," i.e., the hold, "generates the clamor of your protest" (6; emphasis added), and second, when the narrator, now embodying the voice of the captives, tells the "vieil Océan" that the shore of the New World is where "we hook our tar-streaked wounds, our reddened mouths and stifled outcries" (7; emphasis added). ${ }^{31}$ In the first instance, Glissant asks us to imagine the survivors as a loud crowd dominated by confusion, indignation, and passion, and expressing dissent or protest. Etymologically, a "clamor" is also a call or an appeal-in other words, a claim. As early as the 14th century, a claim was "a demand of a right [and] right of claiming," implying a sense of entitlement with moral and legal prerogatives. As a verb, the legal dimension of claim was accentuated: "to ask or demand by virtue of right or authority." It is

30 Article 1 of the United Nations Convention relating to the Status of Refugees (1951), states that "the term 'refugee' shall apply to any person who ... owing to a well-founded fear of being persecuted for reasons of race, religion, nationality, membership of a particular social group or political opinion, is outside the country of his nationality and is unable or, owing to such fear, is unwilling to avail himself of the protection of that country; or who, not having a nationality and being outside the country of his former habitual residence as a result of such events, is unable or, owing to such fear, is unwilling to return to it" (UNHCR).

31 Both the terms "clamor" in the third paragraph and "outcries" in the eighth paragraph are translations of the term "clameur" in the original. Also, note that the eighth paragraph of "The Open Boat" begins with a line from Lautréamont's Les Chants de Maldoror (1868): “Je te salue, vieil Océan!” (7). Betsy Wing, the translator, must have chosen to leave the line in French to make the Lautréamont reference explicit. 
this "right of claiming" that is stifled in the second instance: Plantation slaves knew better than to complain, and they had no legal rights whatsoever. Thus, for Glissant to evoke the notion of claim in relation to the survivors of the Middle Passage is neither anachronistic (since the use of the term predates the early stages of European slave trading in Africa) nor unfounded (since Middle Passage survivors are entitled, if only in a moral sense, to claim their rights). And the legal claims of today's migrants, in virtue of international refugee law, are based on the same moral principle with which Glissant endows those who survived the experience of the hold. The outcry/clamor/ claim of the migrants has reached the shores of affluent nations, and these nations can no longer turn a deaf ear to them.

\section{Migrants and Nation-States}

The recourse to Glissant's "trace-thinking" to establish a parallel between the deported Africans of the past and the migrants of today is not a new idea. A typical example is Alexandre Alaric's essay on the figure of the "naked migrant" (2005). Alaric first revisits the Glissantian trope of birth, comparing the experience of today's migrants to “a second 'coming to the world,' a second hoped-for birth" (188), and later to a "proto-genesis of self and the world" (193). Further on, Alaric calls "tracethinking" a "social strategy of resistance" (193) implemented by both the victims of the slave trade and modern-day migrants. Alaric argues that the latter, in their quest to be granted a legal status in Europe or North America, challenge the notions of conventional citizenship and national borders. Indeed, nation-states are being shaped and defined anew by the global phenomenon of migrancy. Whether the slaves of yesterday and the migrants of today resist or embrace the new culture they end up in, they alter it with their own values, beliefs, and practices, even when all is done to minimize, or even uproot, these cultural legacies. The ineluctable consequence of this global phenomenon, regardless of laws, borders, politics, and ideologies, is the accelerated creolization of nation-states, which, fearing for their stability, try to protect themselves by fostering social uniformization.

The stability of a nation-state is based on a social contract that is rather impervious, if not hostile to outsiders. And it is not just a social contract; it is also a social construct. Benedict Anderson's well-known concept of the nation as an "imagined" community "always conceived as a deep, horizontal comradeship" (8) could not be more accurate in that it is, indeed, "imagined." Fraternity and equality among nationals rarely stands the test of reality. Furthermore, the notion that a community is "imagined" points to a discourse of self-authentication-in other words, a fantasy akin to a nationalist rhetoric that Glissant describes as rootedness-rootedness that has been clashing with the uprootedness of recent mass migration. The current wave of forced diaspora has created favorable conditions for what Glissant calls errantry, a notion 
whose genealogy harkens back to the Deleuzian notion of the rhizome. Errantry, like the rhizome, "is at variance with territorial intolerance, or the predatory effects of the unique root" (20). It is akin to an endless creolization that goes against the idea of the nation-state as a monolithic organization characterized by fixed, univocal rules and rejection of outside influences: "[T]his thinking of errantry, this errant thought," Glissant argues, "silently emerges from the destructuring of compact national entities that yesterday were still triumphant and, at the same time, from difficult, uncertain births of new forms of identity that call to us" (18). Relation, rather than opposition, defines these new forms of identity, which are fluid and independent. As Glissant explains: "The thought of errantry is not apolitical nor is it inconsistent with the will to identity, which is, after all, nothing other than the search for a freedom within particular surroundings" (20). If errantry denotes a geographical displacement, it is also a psychological move, a rational decision to shift one's perspective on the world and redefine one's identity in the process. Our fragmented, chaotic age seems a propitious time to prompt our latent disposition to the thought of errantry, but this does not mean that populations currently undergoing the migration crisis are motivated by the same thought. It is no wild speculation to argue that some migrants, whatever their origins, affinities, and destinations, will seek to re-establish themselves as a homogeneous community wherever they land, and will vie for power either against other minorities or their host country. Their destiny is not a matter of ethical choices. It is contingent on a series of conditions over which they hold little or no sway. Upon arrival, the migrants are faced with what Marinus Ossewaarde calls "elements of sociality," which include "customs, habits, manners, mores, values, folkways, meanings, beliefs, ideas, sentiments, taste, symbols, language and local patriotism” (381). The success of the negotiation between the migrants and their host nation will depend on how they apprehend each other's culture.

The world is now thrust into a cycle of incessant migration, pitting a state-centric against an extra-statist perspective. Undeniably, national authorities view the mobility of migrants as a threat because it eludes state control and laws. However, comparing nation-states to monsters of selfishness and migrants to prophets of creolization is an over-simplification. A host country is built around rules, values, and traditions holding people together, but so is the nation that the migrant fled, and the shock of displacement does not eradicate the culture of origin to the extent the transatlantic slave trade did. Slave traders and masters carried out the erasure of African identities knowingly and intentionally. It was part of a process of absolute subjugation. There is no such endeavor today: Immigration is a negotiation between a will to adopt on the part of the host, and a will to adapt on the part of the newcomer. Whatever the level of good faith on either side of the equation, identities are being transformed. As Nevzat Soguk puts it, "Lives are being recast partly in migrant trajectories, partly in territorial imperatives and partly in national imaginations” (419). The migrants' primary purpose is survival, and "in their wanderings," Soguk notes, they are "creative, resourceful, and resistant, demonstrating the possibilities of establishing new 
homes, neighborhoods, and communities” (437). While doing so, however, they challenge "modern territorial statecraft" (437). Large-scale immigration shakes the economic, demographic, social, cultural, and political foundations of nationhood.

On March 11, 1882, on the occasion of a conference at the Sorbonne, Ernest Renan famously described a nation as a "daily plebiscite." A nation, according to Renan, is "a soul, a spiritual principle" defined by a past, i.e., "the possession in common of a rich legacy of memories," and a present, which requires "consent and the desire to live together, the desire to continue to invest in the heritage that we have jointly received." Speaking directly to his audience that day, Renan declares: "Messieurs, man does not improvise. The nation, like the individual, is the outcome of a long past of efforts, sacrifices, and devotions." And he concludes, "One loves [the nation] in proportion to the sacrifices that one has committed and the troubles that one has suffered." Renan's understanding of the nation as a "spiritual principle" has the virtue of overriding such criteria as race, religion, language, and geography, thus suggesting that anyone willing to be part of the nation can do so in exchange for a steadfast commitment to national values and customs. The alleged continuum between past and present, however, brings newcomers to an impasse, for even if they are willing to embrace the ethos of the national community, they cannot possibly claim a past connection to that community. For a newly arrived migrant, the past is yet to come-as it were. Renan must have been aware of this paradox as he notes that national solidarity is the fruit not only of past sacrifices but also sacrifices one is ready to make in the present. Hence Renan also insists on "consent, the clearly expressed desire to continue a common life.” One final issue must be raised about Renan's argument: It presupposes unqualified allegiance to the nation on the part of the newcomer, but it overlooks the tractability, goodwill, and responsibility that lie with the host nation. It is understood that the contact of cultures, whether in the form of confluence or clash, generates changes, but the extent to which a host nation should accept or reject the cultural baggage newcomers bring with them remains a moot point.

Cosmopolitanism, both as a moral stance and a national policy, is often invoked as a panacea to such crises as the recent wave of immigration into the European Union. The idea of a cosmopolitan world is not new, and yet no nation has ever abolished its borders in order to welcome all refugees and asylum seekers. Etienne Balibar observes that the notion of "cosmopolitical utopias" (293) is countered by "the conviction that ... there is no citizen without a membership in a 'community of citizens' built through a common history, which therefore has to be geographically and culturally bordered" (294). In Idea for a Universal History from a Cosmopolitan Perspective (1784), Immanuel Kant imagines a "federation of peoples" in which "every state ... could expect its security and its rights" to emanate "from a united power and from the decision based on laws of the united will" (10). But Kant does not explain how such supranational institutions would be organized, and a decade later, in Toward Perpetual Peace: A Philosophical Sketch (1795), he shifts his attention to what Balibar describes as: 
a universal system of juridical norms, which include certain basic or fundamental rights: particularly the right of "hospitality," which make it possible for private individuals to move across borders and settle on "foreign land." The main question becomes that of the moral transformation that states must undergo, i.e., impose upon themselves, if they are to ... respect and legalize the "cosmopolitan right" of individuals. (295-296)

Balibar notes that the purpose of this "cosmopolitan right" is for states "to emancipate individuals" (295-296), and that it should not be confused with "a variety of international law, whose subjects remain the individual 'sovereign nations' " (295-296). But Jacques Derrida brushes aside this difference and conflates individual rights and international law when he takes on Kant's notion of hospitality. In Perpetual Peace, Kant defines the "conditions of universal hospitality" as:

the right of a stranger not to be treated in a hostile manner by another upon his arrival on the other's territory. If it can be done without causing his death, the stranger can be turned away, yet as long as the stranger behaves peacefully where he happens to be, his host may not treat him with hostility. It is not the right of a guest that the stranger has a claim to ... but rather a right to visit, to which all human beings have a claim, to present oneself to society by virtue of the right of common possession of the earth. (82)

Kant's notion of a "right to visit" falls short of the need in which current refugees and asylum seekers find themselves: They are not requesting a right to visit but a right to stay for the simple reason that they have nowhere else to go. Similarly, the proviso that "the stranger can be turned away" so long as the life of the stranger is not in peril seems inappropriate for the current situation. International laws have been established to prevent nations from refusing migrants in a dire situation, and most nations endeavor to be hospitable. Yet, some do shirk their responsibilities, and even when they don't, hospitality is always subject to conditions. It is this conditionality that Derrida challenges in Of Hospitality (1997). “Absolute hospitality,” Derrida argues:

requires that I open up my home and that I give not only to the foreigner (provided with a family name, with the social status of being a foreigner, etc.), but to the absolute, unknown, anonymous other, and that I give place to them, that I let them come, that I let them arrive, and take place in the place I offer them, without asking of them either reciprocity (entering into a pact) or even their names. (25)

But hospitality, according to Derrida, can never be unconditional as it is mediated by power. This power starts at the level of the individual: "I want to be master at home. ... Anyone who encroaches on my 'at home,' ... on my power of hospitality, on my sovereignty as host, I start to regard as an undesirable foreigner, and virtually as an enemy" $(53,55)$. Sovereignty, Derrida continues, "can only be exercised by filtering, choosing, and thus by excluding and doing violence” (55). Pointing out, after Émile Benveniste, that hostis, the Latin root of hospitality, means both guest and enemy (45), Derrida contends that hospitality is constituted by "a certain injustice, and even a certain perjury” (55). Derrida's shift from injustice to perjury marks a shift 
from both moral to legal issues and individual to national issues. Indeed, Derrida's reflection on hospitality is a response to the rather harsh treatment of undocumented laborers in Paris back in the mid-1990s. ${ }^{32}$

Derrida speaks of collusion between hospitality and power, which starts with "the necessity, for the host ... of choosing, electing, filtering, selecting their invitees, visitors, or guests, those to whom they decide to grant asylum, the right of visiting, or hospitality" (55). Derrida shows that hospitality, initially understood as a moral imperative, has become a matter of legal rights, contending that "[the] collusion between the violence of power or the force of law ... on one side, and hospitality on the other, seems to depend, in an absolutely radical way, on hospitality being inscribed in the form of a right" (55). The issue that Derrida raises, Gerasimos Kakoliris argues, is that "this asymmetry between conditional and unconditional hospitality maintains an endless demand, since each event of welcoming the other can only fall short of the requirements of the unconditional law of unlimited hospitality" (149). Thus, Derrida admits that there is an unresolved tension between moral and political responsibility since the obligation to welcome the other is thwarted by issues of national security; yet, Derrida faults nations for restricting entry and residency into their territory. As Kakoliris points out, even though Derrida demonstrates that conditional and unconditional hospitality are "inseparable" (150), he opposes them and thus creates a binary opposition, which is exactly what deconstruction offers to undo. "It is quite paradoxical," Kakoliris continues, "to find [Derrida] talking of 'pure' hospitality, 'real hospitality,' 'true hospitality,' when he is the philosopher par excellence who has put the concepts of 'purity' and 'truth' under question” (151). In Limited Inc, Derrida himself argues that, "there is no idealization that keeps itself pure, safe from all contamination" (119), which means that there cannot be an absolute, pure opposition between two terms because one term always contaminates the other. Hence Kakoliris concedes that there is a certain hostility in every act of hospitality, but he rejects Derrida's theory of “a 'pure,' 'real' or 'true' hospitality” (151). Kakoliris finally challenges Derrida's theory for implying that one is never hospitable enough, which puts everyone in a state of permanent guilt. Responsibility to others cannot be a com-

32 In 1996, in the wake of the "sans-papiers" movement in Paris, Derrida lambasted the French government for its treatment of undocumented African workers: "I remember a bad day last year: It just about took my breath away, it sickened me when I heard the expression for the first time, barely understanding it, the expression crime of hospitality [délit d'hospitalité]. In fact, I am not sure that I heard it, because I wonder how anyone could ever have pronounced it ... no, I did not hear it, and I can barely repeat it; I read it voicelessly in an official text. It concerned a law permitting the prosecution, and even the imprisonment, of those who take in and help foreigners whose status is held to be illegal. This 'crime of hospitality' (I still wonder who dared to put these words together) is punishable by imprisonment. What becomes of a country, one must wonder, what becomes of a culture, what becomes of a language when it admits of a 'crime of hospitality,' when hospitality can become, in the eyes of the law and its representatives, a criminal offense?” (Qtd. in Kakoliris 144-145). 
plete surrendering of one's decisional power. As David Wood argues, “our exposure to the other is not some huge, excessive obligation, but rather a complex openness to requests, demands, pleas, which call not just for an acknowledgement of my obligations, but for scrutiny, for negotiation, for interpretation, and ultimately for recognizing both opportunities and limitations" (qtd. in Kakoliris 152-153). Wood's assessment also applies to the impact of newcomers on a host country, and it could be argued that responsibility, despite the newcomers' indigence, goes both ways. In fact, responsibility, understood as reliability and trustworthiness, may well be the first quality most migrants wish to display.

This encounter between the guest and the host is not a set trajectory. For the migrant, it is an adventure (from the Latin ad-venire, to reach, to arrive at) shared with the host in the sense that an adventure is a perilous undertaking in which both sides are bound to lose a part of themselves. An adventure implies danger, risk, and unpredictability. It is uncharted territory, a form of improvisation that may well be the very essence of the nation-to-be, for newcomers and their progeny, willingly or not, will modify the national identity. The only way to imagine the consequences of the current mass migration is to imagine the kind of citizens these immigrants, and more importantly, their progeny, will become.

Gilles Deleuze and Félix Guattari's concept of the rhizome is the cornerstone of Glissant's theory of Relation: "Rhizomatic thought," Glissant writes in Poetics of Relation, "is the principle behind what I call the Poetics of Relation, in which each and every identity is extended through a relationship with the Other" (11). While the rhizome is an apt metaphor to describe Relation, it is rather unfitting to describe the actual cultural and personal transformation the migrant undergoes once settled in the host nation. In fact, the Glissantian notion of rhizome-identity, with its network of infinite, unpredictable encounters, as well as its horizontal and constantly broken trajectories, may not be an adequate model of identity for people who have lost their roots and everything that was familiar. Glissant's argument, in Poetics of Relation, that invaders of the distant past were ruled by an irrepressible desire to settle down is also valid for the current victims of forced migration, except that the latter are not driven by a desire but by an imperative: survival. In their quest for stability, displaced populations aspire to sedentariness, knowing full well that their and their progeny's identities will be modified in the process. Displacement implies not only adaptability and negotiation, but also emergence of new identities. In order to provide an alternative to Deleuze and Guattari's botanical metaphor, one could invoke marcottage, a form of plant propagation that differs from propagation by cuttings. Marcottage, sometimes called air layering, consists in burying part of a stem or branch in the soil until new roots develop. ${ }^{33}$ Marcottage does not change the genetic identity of the new

33 In this process called rhizogenesis, the part of the stem or branch buried in the soil is not separated from the parent plant. From a genetic point of view, however, marcottage remains akin to propaga- 
plant, but it remains a potent metaphor for migrants in that the development of the plant will depend on the nature of the soil (lighting, shade, humidity, dryness, acidity, etc.) where it is rooted. ${ }^{34}$ Furthermore, the descendants of these plants may generate hybrids by crossbreeding with plants that have been around since long before they were. Beyond the obvious parallel with the offspring of migrants who will take root in the host soil and develop identities reflecting a more or less ideal, acknowledged, and accepted compromise between various cultures, marcottage brings back the reviled notion of rootedness to the fore, neither to laud nor loathe it, but to convey its new meaning in this age of mass migration. The future young shoots may be enrooted and attached to their new soil, but their enrooting is likely to be creolized, diverse, and immune to the "totalitarian root" to whose eradication Glissant has devoted so much energy.

\section{Works Cited}

Alaric, Alexandre. "Le Migrant Nu: 'Le déporté sur des frontières.' " Multitudes, vol. 3, no. 22, 2005, pp. 187-202.

Anderson, Benedict. Imagined Communities: Reflections on the Origin and Spread of Nationalism. 1983. Verso, 2016.

Balibar, Etienne. "Citizenship of the World Revisited." Routledge Handbook of Cosmopolitanism Studies, edited by Gerard Delanty, Routledge, 2012, pp. 291-301.

Black, Daniel. The Coming: A Novel. Saint Martin's P, 2015.

Bongie, Chris. Friends and Enemies: The Scribal Politics of Post/colonial Literature. Liverpool UP, 2008.

D’Aguiar, Fred. Feeding the Ghosts. The Ecco P, 1997.

Derrida, Jacques. Limited Inc. Edited by Gerald Graff, translated by Jeffrey Mehlman and Samuel Weber, Northwestern UP, 1988.

---. Of Hospitality: Anne Dufourmantelle Invites Jacques Derrida to Respond. Translated by Rachel Bowlby, Stanford UP, 2000.

Glissant, Édouard. Caribbean Discourse: Selected Essays. 1981. Translated by J. Michael Dash, UP of Virginia, 1989.

--.. Creolization in the Making of the Americas." Caribbean Quarterly, vol. 54, no. 1-2, 2008, pp. 81-89.

---. Introduction à une poétique du divers. Gallimard, 1996.

---. Poetics of Relation. Translated by Betsy Wing, U of Michigan P, 1997.

--.. Poétique de la Relation (Poétique III). Gallimard, 1990.

--.. The Open Boat." Poetics of Relation. Translated by Betsy Wing, U of Michigan P, 1997, pp. 5-9.

tion by cuttings in that it is a mode of asexual multiplication that generates new individuals with the same genome. Put simply, these new individuals are clones. By contrast, sexual reproduction (e.g., flower pollination) produces new individuals with a new genome, which is a mixture of both parents. 34 I am most grateful to Professor Christine Jourdan for her scientific guidance on marcottage. 
--.. The Unforeseeable Diversity of the World." Beyond Dichotomies: Histories, Identities, Cultures, and the Challenge of Globalization, edited by Elisabeth Mudimbe-Boyi, translated by Haun Saussy, SUNY P, 2002, pp. 287-296.

--.. Traité du Tout-Monde (Poétique IV). Gallimard, 1997.

Hayden, Robert. “Middle Passage." Collected Poems. 1962. Edited by Frederick Glaysher, Liveright, 2013, pp. 48-54.

Hayes, Jarrod. Queer Roots for the Diaspora: Ghosts in the Family Tree. U of Michigan P, 2016.

Hyatt, Vera Lawrence, and Rex Nettleford, editors. Race and the Origin of the Americas: A New World View. Smithsonian Institution P, 1995.

Kant, Immanuel. Idea for a Universal History from a Cosmopolitan Perspective (1784). Toward Perpetual Peace and Other Writings on Politics, Peace, and History (Rethinking the Western Tradition), edited by Pauline Kleingeld, translated by David L. Colclasure, Yale UP, 2006, pp. 3-16.

---. Toward Perpetual Peace: A Philosophical Sketch (1795). Toward Perpetual Peace and Other Writings on Politics, Peace, and History (Rethinking the Western Tradition), edited by Pauline Kleingeld, translated by David L. Colclasure, Yale UP, 2006, pp. 3-16.

Lautréamont, Comte de. Les Chants de Maldoror. 1868. Translated by Guy Wernham, New Directions, 1965.

Joignot, Frédéric. “Pour l'écrivain Édouard Glissant, la créolisation est 'irréversible.' ” Le Monde, 4 Feb. 2011, www.lemonde.fr/disparitions/article/2011/02/04/pour-l-ecrivain-edouard-glissantla-creolisation-du-monde-etait-irreversible_1474923_3382.html. Accessed 11 Aug. 2017.

Kakoliris, Gerasimos. "Jacques Derrida on the Ethics of Hospitality.” The Ethics of Subjectivity: Perspectives since the Dawn of Modernity, edited by Elvis Imafidon, Palgrave Macmillan, 2015, pp. 144-156.

Morrison, Toni. Beloved: A Novel. Picador, 1988.

Ossewaarde, Marinus. "Cosmopolitanism and the Society of Strangers." Current Sociology, vol. 55, no. 3, 2007, pp. 367-388.

Phillips, Caryl. The Atlantic Sound. Vintage-Random House, 2001.

Renan, Ernest. “What is a Nation?” Translated by Ethan Rundell, ucparis.fr/files/9313/6549/9943/ What_is_a_Nation.pdf. Accessed 14 Aug. 2017.

Soguk, Nevzat. "Poetics of a World of Migrancy: Migratory Horizons, Passages, and Encounters of Alterity.” Global Society, vol. 14, no. 3, 2000, pp. 415-442.

Tamby, Jean-Luc. "The Sorcerer and the Quimboiseur: Poetic Intention in the Works of Miles Davis and Édouard Glissant." American Creoles: The Francophone Caribbean and the American South, edited by Martin Munro and Celia Britton, Liverpool UP, 2012, pp. 147-164.

UNHCR. United Nations Convention relating to the Status of Refugees. 1951. UNHCR, www.unhcr. org/3b66c2aa10. Accessed 12 Aug. 2017. 